\title{
Cross-Talk of Breast Cancer Cells with the Immune System
}

\author{
Sandra Demaria, Karsten A. Pilones and Sylvia Adams \\ New York University School of Medicine and NYU Langone Medical Center, New York, NY, \\ United States
}

\section{Introduction}

Understanding the pathogenesis of breast and other cancers requires an improved understanding of the local microenvironment in which cancer develops and progresses (Hanahan and Weinberg, 2011). Many cell types have been defined as key components of the tumor stroma that contributes to tumor growth and metastasis, and modulates the response to treatment. In this chapter we will focus on cells of the immune system, critical players with dual function comprising cells that can foster a pro-tumorigenic inflammatory environment as well as reject tumors (Demaria et al., 2010). Importantly, the therapeutic manipulation of the host immune system has a tremendous potential to enhance the response of breast cancer patients to treatment. Therefore, it is imperative to understand the cross-talk between breast cancer cells and cells of the innate and adaptive immune system.

Several cell communication systems are involved in this cross-talk, including proinflammatory and immunosuppressive cytokines, chemokines and endogenous danger signals, known as damage-associated molecular pattern (DAMP) molecules that bind to Toll-like Receptors (TLR). Some of these factors represent interesting targets for immunotherapy strategies based on their known ability to stimulate the immune system, but in the context of the tumor microenvironment these immune stimulatory agents may also produce unwanted pro-tumorigenic effects by binding to receptors ectopically expressed on the cancer cells. Others are involved in recruiting to the tumor immune cells with regulatory and immune suppressive functions that protect the tumor from immune rejection. Clearly, the cross-talk between epithelial cells and the immune system is distorted in cancer to promote tumor growth and progression.

We will review pre-clinical and clinical data in support of the concept that the cross-talk between neoplastic and immune cells is a key determinant of tumor behavior and treatment outcomes. The mediators of this cross-talk that have been identified in breast cancer will be discussed. Ultimately, improved understanding of the potential double-edge sword quality of therapies targeting mediators of this cross-talk is essential for a cautious use of immune response modifiers to harness the positive (anti-tumor immune reactivity) without promoting the negative (tumor growth, immune suppression) effects.

\section{Immune cells infiltrating breast cancer}

The presence of an inflammatory infiltrate in benign breast is not uncommon and may be seen in association with a variety of fibrocystic changes or conditions such as mammary 
duct ectasia. However, for the most part immune cells are not a significant component of the normal breast stroma. In contrast, a marked increase in adaptive and innate immune cells often accompanies the process of carcinogenesis, with prominent inflammatory infiltrates seen around ducts involved by in situ carcinoma, as well as within invasive breast cancers (figure 1) (DeNardo and Coussens, 2007). The innate immune system plays a major role in maintenance of tissue homeostasis and reacts to tissue disruption, including physiological tissue disruption that occurs in the breast during branching morphogenesis at puberty and pregnancy, and in post-weaning involution. Macrophages, for example, have been shown to be important regulators of these processes (Gyorki and Lindeman, 2008). These physiological processes are self-limiting and the inflammation associated with them resolves once tissue homeostasis is restored. In contrast, carcinogenesis is a chronic process, often characterized by disorderly proliferation and death of the neoplastic cells, such as seen in ductal carcinoma in situ (DCIS). Deregulated cell death can foster a status of chronic inflammation, possibly due to the release of DAMPs from the dying cells (Mantovani et al., 2008; Zeh and Lotze, 2005). Death of epithelial cells that have undergone or are undergoing transformation also releases tumor-associated antigens and can result in activation of tumorspecific $\mathrm{T}$ and $\mathrm{B}$ cell responses. These immune responses can prevent tumor outgrowth, but eventually genetically unstable cancer cells give rise to variants that have become resistant to the recognition and/or killing by immune effector cells, a process defined as immunoediting (Schreiber et al., 2011). Escape from immune control does not necessarily require the loss of the antigen(s) recognized by $\mathrm{T}$ cells, but it is a complex process involving the production of immunosuppressive cytokines and the recruitment of regulatory innate and adaptive immune cells that protect the tumor from rejection. Key players in development and maintenance of the pro-tumorigenic environment are myeloid cells and subsets of CD4 T cells functionally differentiated towards T-helper type 2 (Th2) and regulatory (Treg) phenotypes that actively maintain a state of tolerance to the tumor (Disis, 2010). The contribution of Th2 CD4 cells has been recently demonstrated in an experimental study showing that interleukin (IL)-4 produced by Th2 CD4 T cells regulates the function of macrophages and promotes their pro-tumorigenic M2 phenotype in a mouse breast cancer model (Allavena et al., 2008; DeNardo et al., 2009). Interestingly, IL-4 has also been shown to be produced by primary epithelial breast cancer cells and to serve as an autocrine survival factor (Todaro et al., 2008). Another Th2 cytokine, IL-13, was shown to be involved in growth of human breast cancer cells (Aspord et al., 2007). Finally, a correlation between the number of Treg infiltrating human breast cancer and worse prognosis was reported in a study of 62 patients with DCIS and 237 patients with invasive breast cancer (Bates et al., 2006).

Conversely, evidence of effective anti-tumor immunity limiting tumor growth has been reported in several studies. Presence of a gene signature rich in Th1 and CD8 T cell markers was associated with a better outcome regardless of the type of epithelial malignancy in a study analyzing the stroma of primary breast cancers (Finak et al., 2008). Other studies, however, found that the prognostic value of immune signatures is different depending on the molecular subtype of breast cancer, and is a dominant factor in hormone receptors- and human epidermal growth factor receptor (Her)-2-negative (triple negative) cancers (Calabrò et al., 2009; Desmedt et al., 2008; Kreike et al., 2007; Mahmoud et al., 2011).

Overall, accumulating data support the concept that the balance between pro-tumorigenic and anti-tumor immune reactions is a key determinant of breast cancer progression. As 
detailed below, the neoplastic epithelial cells both secrete and respond to cytokines, chemokines and other bioactive molecules that regulate the recruitment and function of immune cells.

A
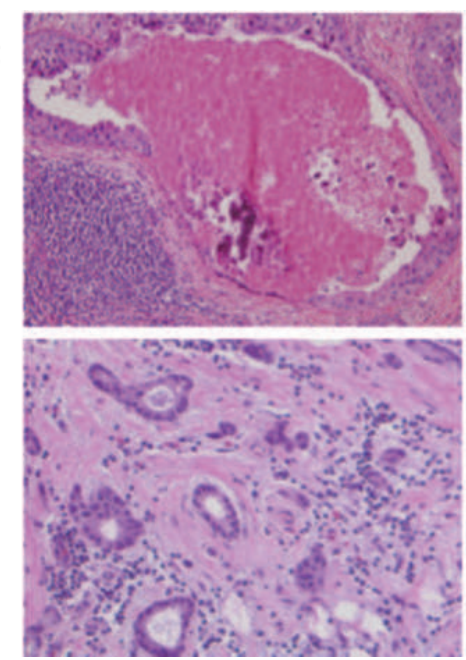

B

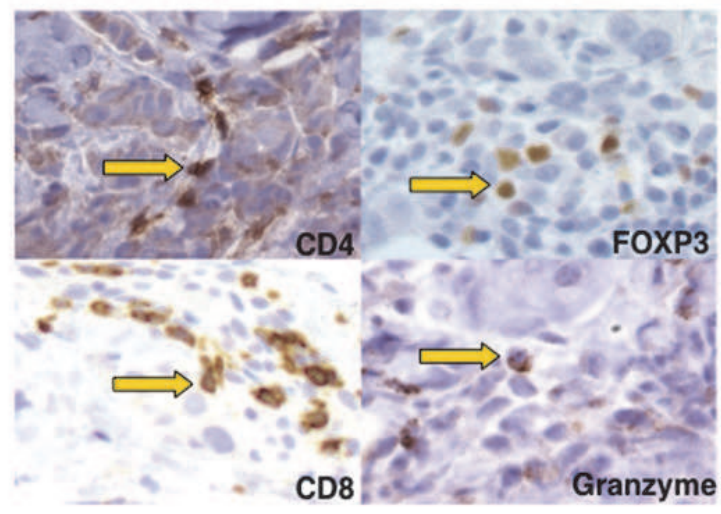

Fig. 1. Example of immune infiltrate in breast cancer. (A) Lymphocytic infiltrate as seen in H\&E-stained sections. Ductal carcinoma in situ (DCIS) with comedo necrosis (upper panel), well differentiated invasive ductal carcinoma (lower panel). (B) Immunohistochemical staining of intratumoral T cells for markers of helper T cells (CD4), regulatory T cells (FoxP3), and effector T cells (CD8 and granzyme).

\section{Chemokines and cytokines produced by breast cancer cells}

A large network of chemokines and their receptors regulate trafficking and recruitment of innate and adaptive immune cells to different tissues in response to inflammation (Kunkel and Butcher, 2002). Signaling via chemokine receptors regulates processes such as cell migration, invasion, interaction with the endothelium and extracellular matrix, as well as survival. Interestingly, many epithelial cells acquire the expression of chemokine receptors and/or secrete chemokines when they undergo neoplastic transformation (Balkwill, 2004). The production of chemokines by cancer cells has been shown to influence the degree and phenotype of the inflammatory infiltrate. For example, the chemokine CCL2 (also known as monocyte chemotactic protein-1, MCP-1) is frequently secreted by breast cancer cells and is primarily responsible for recruitment of monocytes to tumors (Ueno et al., 2000; Valković et al., 1998). Within the tumor microenvironment monocytes differentiate into tumorassociated macrophages (TAM), which play a role in cancer progression and metastasis by producing immunosuppressive cytokines and pro-angiogenic factors (Pollard, 2004; Ueno et al., 2000). In human breast cancer levels of CCL2 correlate with a poor prognosis (Saji et al., 2001; Ueno et al., 2000) and recent evidence indicates that CCL2 plays a key role in pulmonary metastases of breast cancer by recruiting Gr1+ inflammatory monocytes (Qian et al., 2011). Another chemokine produced by breast cancer cells and implicated in recruitment of monocytes is CCL5 (also known as Rantes) (Luboshits et al., 1999). Co-expression of CCL5 
with CCL2 was reported to be associated with more advanced breast cancer stage (Soria et al., 2008).

Levels of two pro-inflammatory and pro-angiogenic chemokines, CXCL8 (also known as IL8) and CXCL1 (also known as Growth-related oncogene, GRO) were found to be significantly elevated in sera of metastatic breast cancer patients with Her-2-positive compared with Her-2-negative cancers (Vazquez-Martin et al., 2007). In vitro, overexpression of Her-2 in human breast cancer cells MCF7 led to a marked increase in release of CXCL8 and CXCL1 that was abrogated by treatment with the tyrosine kinase inhibitor geftinib (Iressa), suggesting that these chemokines may play a role in the aggressive behavior of Her-2-positive breast cancers (Vazquez-Martin et al., 2007). CXCL1 and CXCL8 recruit neutrophils to tumors, and there is evidence that in the tumor microenvironment these cells acquire a pro-tumor phenotype in response to transforming growth factor (TGF) $\beta$ (Fridlender et al., 2009).

Secretion of the chemokines CCL20 (also known as macrophage inflammatory protein, MIP$3 \alpha$ ) and CCL19 (MIP-3 $\beta$ ) by human breast cancer cells has been implicated in the recruitment of immature dendritic cells (DC) to breast cancer but the prognostic value remains uncertain (Bell et al., 1999; Treilleux et al., 2004). Interestingly, infiltration of breast cancer by Treg cells, which are recruited by CCL22 produced by approximately $60 \%$ of breast cancers (Gobert et al., 2009), was found to be associated with increased risk of relapse (Bates et al., 2006).

Conversely, some chemokines produced by breast cancer cells enhance recruitment of antitumor T cells. One such example is CXCL16, a chemokine that is up-regulated during inflammation in peripheral tissues and promotes recruitment of activated CD8 and Th1 T cells (Sato et al., 2005; Yamauchi et al., 2004). This may explain why the levels of expression of CXCL16 in colorectal carcinoma correlate with increased infiltration of tumors by T cells and better prognosis (Hojo et al., 2007). We were the first to report the expression of CXCL16 by human and mouse breast cancer cells, and to show that CXCL16 is markedly induced in vitro and in vivo by treatment with radiotherapy (Matsumura et al., 2008). We also showed in a mouse model of metastatic breast cancer that induction of CXCL16 by radiotherapy enhanced tumor infiltration by CD8 T cells elicited by immunotherapy promoting immunemediated tumor rejection (Matsumura et al., 2008). Data in the preclinical model suggest that CXCL16 may play a role in response to treatment with radiotherapy and immunotherapy. Although the prognostic value of the expression of CXCL16 in breast cancer remains to be determined, it is possible that in the absence of treatment-induced antitumor CD8 T cells the lymphocytes recruited to CXCL16 tumors may instead promote protumorigenic inflammation, as suggested in prostate cancer (Darash-Yahana et al., 2009). Whether the pro- or anti-tumor effects of CXCL16 prevail may be determined by expression of the cognate receptor, CXCR6, by the cancer cells, as discussed in the next section. Overall, chemokines expressed by breast cancer cells play critical roles in shaping the tumor immune infiltrate and likely influence tumor progression and response to treatment.

Among cytokines produced by breast cancer cells, the role of TGF $\beta$ in tumor development and progression has been extensively studied. Acting as a tumor suppressor early on, TGF $\beta$ later becomes a key factor in promoting tumor progression, metastases, and resistance to treatment (Barcellos-Hoff and Akhurst, 2009). Relevant to the focus of this chapter, in addition to direct effects on the neoplastic cells, TGF $\beta$ acts on innate and adaptive immune cells suppressing their function (Gorelik and Flavell, 2001; Wrzesinski et al., 2007). DCs 
(Kobie et al., 2003) and effector CD8 T cells (Gorelik and Flavell, 2001; Thomas and J., 2005; Wrzesinski et al., 2007) are key targets of TGF $\beta$ suppressive effects in cancer leading to defects in activation and function of anti-tumor effector cells. Interestingly, an unexpected tumor-promoting effect of TGF $\beta$ was shown to be mediated by induction of production of the pro-inflammatory cytokine IL-17 by CD8 T cells (Nam et al., 2008). IL-17 acted as a survival factor for tumor cells, including mouse breast cancer cell lines that ectopically expressed the IL-17 receptor (Nam et al., 2008). These intriguing observations emphasize the complexity of interactions between tumor cells and immune system. Breast cancer cells also produce IL-4 and use it as an autocrine survival factor (Todaro et al., 2008).

The expression and production of IL-10 and IL-12 p40, but not of IL-12 p70, by human breast tumor cells was recently reported (Heckel et al., 2011). IL-10 has immunosuppressive antiinflammatory effects, and IL-12p40 can bind to IL-12 receptor on immune cells and work as an antagonist of IL-12p70, a cytokine that promotes Th1 T cell differentiation. Although the contribution of IL-10 and IL-12p40 produced by breast cancer cells to generation of an immune suppressive tumor microenvironment remains to be further studied, data support the concept that tumors that become clinically apparent have undergone multiple changes to escape immune rejection (Schreiber et al., 2011).

\section{Chemokine receptors expressed by breast cancer cells}

Cancer cells express several chemokine receptors, and exploit the chemokine system to home to bone marrow and different organs that are sites of metastases. An example is CXCR4, the chemokine receptor most commonly found on cancer cells and the role of which has been more extensively characterized (Balkwill, 2004). In vitro, binding of CXCR4 to its ligand, the chemokine CXCL12 (also known as stromal derived factor -1, SDF-1) activates migration and invasion of cancer cells. In vivo, expression of CXCR4 is associated with metastatic capacity in melanoma, breast, and other cancers (Balkwill, 2004; Muller et al., 2001). Another chemokine receptor that is required for homing of lymphocytes and DCs to lymph nodes, CCR7, has been shown to be expressed by breast cancer cells and guide their metastases to lymph nodes (Muller et al., 2001).

CXCR3, a chemokine receptor expressed by activated Th1 and effector CD8 T and natural killer (NK) cells, binds to three chemokines, CXCL9, CXCL10 and CXCL11. Overexpression of CXCL10 (also known as interferon (IFN)- $\gamma$ inducible protein 10, IP-10), or CXCL9 (also known as monokine induced by IFN- $\gamma$, Mig) by genetic engineering of tumor cells in experimental mouse tumor models enhanced recruitment of T and NK cells and promoted immune-mediated tumor rejection (Luster and Leder, 1993; Walser et al., 2007). However, CXCR3 is also expressed by human and mouse breast cancer cell lines (Goldberg-Bittman et al., 2004; Walser et al., 2006), and more recently it was found in all human primary breast cancers tested $(\mathrm{N}=75)$. Importantly, high CXCR3 expression, found in $24 \%$ of the tumors, was associated with poor overall survival (Ma et al., 2009). In experimental mouse models, blocking CXCR3 with a small molecule inhibitor prior to i.v. injection of the tumor cells, or by gene silencing in the tumor cells inhibited metastases (Ma et al., 2009; Walser et al., 2006). Intriguingly, inhibition of lung metastases by CXCR3 gene silencing required NK cells and was compromised in IFN- $\gamma$-deficient mice (Ma et al., 2009). These data highlight the complexity of the interactions between tumor and host, and caution that the systemic use of CXCR3 inhibitors could elicit mixed effects by reducing metastases while potentially interfering also with recruitment of immune cells that are required for metastasis control. 
Similarly to CXCR3, CXCR6 is expressed on immune cells with anti-tumor effector function, namely activated CD8 and Th1 CD4 T cells, NK cells, and NKT cells (Kim et al., 2002; Kim et al., 2001; Nakayama et al., 2003; Unutmaz et al., 2000). CXCL16, the only ligand for CXCR6, was first shown to be expressed by immune cells with antigen-presenting function, and to be up-regulated during inflammation in different organs (Sato et al., 2005; Yamauchi et al., 2004). As mentioned above, expression of CXCL16 was recently described in several tumors, including breast cancer. Autocrine effects of CXCL16 binding to CXCR6 expressed on the same cancer cells were described in prostate cancer, where signaling via CXCR6 induced the activation of AKT/mammalian target of rapamycin (mTOR) pathway and promoted tumor cell invasion, growth and angiogenesis (Wang et al., 2008). In contrast, in renal cell carcinoma, CXCL16 expression was associated with better prognosis in patients. Endogenous CXCL16 appeared to inhibit growth and migration by interacting with CXCR6 expressed by the same tumor cells (Gutwein et al., 2009). Whether the pro- or anti-tumor effects of the CXCL16/CXCR6 pathway depend on the levels of CXCR6 expression on the tumor cells or its interaction with different forms of CXCL16 remains to be clarified. CXCL16 is one of only two chemokines that is released by cleavage of the chemokine domain from a transmembrane molecule by the activity of the disintegrin-like metalloproteinase ADAM10 (Abel et al., 2004). Soluble CXCL16 has chemotactic activity, while the transmembrane form can mediate adhesion to $\mathrm{CXCR6} 6^{+}$cells, as well as function as a scavenger receptor for oxidized low density lipoproteins, phosphatidylserine, and dextran sulfate (Shimaoka et al., 2003). Therefore, it is possible that interaction of CXCR6 expressed on tumor cells with the soluble chemokine domain or the transmembrane form of CXCL16 has different consequences. Expression of CXCR6 was initially reported in mouse breast cancer cell lines (Wang et al., 2006). A recent report in human breast cancer cells shows that CXCR6 can mediate chemotaxis in response to soluble CXCL16. Interestingly, expression of CXCR6 was regulated by hypoxia via hypoxia inducible factor (HIF)-1 $\alpha$, suggesting a role of CXCR6 expressed in breast cancer cells in cell migration in response to hypoxia (Lin et al., 2009). Although intriguing, these findings need confirmation in functional experiments assessing the role of CXCR6 in breast cancer metastasis. Overall, more data is required to clarify the expression and function of CXCR6 in breast cancer.

Another chemokine receptor, CCR5, has been implicated in breast cancer metastases promoted by mesenchymal stem cells. Intriguingly, the increased metastatic ability was dependent on the production of CCL5 by mesenchymal stem cells, which was induced de novo by the breast cancer cells, highlighting the importance of the tumor microenvironment in the cross-talk between neoplastic and stromal cells (Karnoub et al., 2007).

\section{TLR and their ligands}

Immune surveillance by cells of the innate immune system is mediated in large part by pattern recognition receptors (PRRs) that allow sensing of the invading pathogens and initiation of the inflammatory cascade (Kopp and Medzhitov, 2003). PRRs represent a family of evolutionarily conserved, germline-encoded proteins that recognize structural motifs found in bacteria and viruses known as pathogen-associated molecular patterns (PAMPs) (Barton and Medzhitov, 2002). TLRs constitute the most well-studied and characterized family of PRRs. To date, 11 TLRs and their cognate ligands have been identified in humans. TLRs are predominantly expressed in DCs, macrophages and NK cells. TLR activation by their respective PAMPs induces the release of pro-inflammatory cytokines, chemokines as 
well as adhesion molecules that collectively enhance phagocytosis, microbial killing as well as recruitment of adaptive immunity (Iwasaki and Medzhitov, 2004).

In addition to sensing microbial pathogens, TLRs are also activated by endogenous ligands and trigger a sterile form of inflammation. First described by Matzinger as DAMP, these endogenous danger signals are often released or expressed in the context of tissue injury by both normal and neoplastic cells (Bianchi, 2007; Gallucci et al., 1999). Several recently identified DAMPs include heat- shock proteins (Ohashi et al., 2000; Roelofs et al., 2006; Vabulas et al., 2002), uric acid crystals (Liu-Bryan et al., 2005) and extracellular matrix proteins (Okamura et al., 2001) (Figure 2).

DAMP-TLR interactions have been implicated in the pathogenesis of immune dysfunction in autoimmune diseases and atherosclerosis, as well as in the chronic inflammation often associated with cancer (Marshak-Rothstein, 2006).

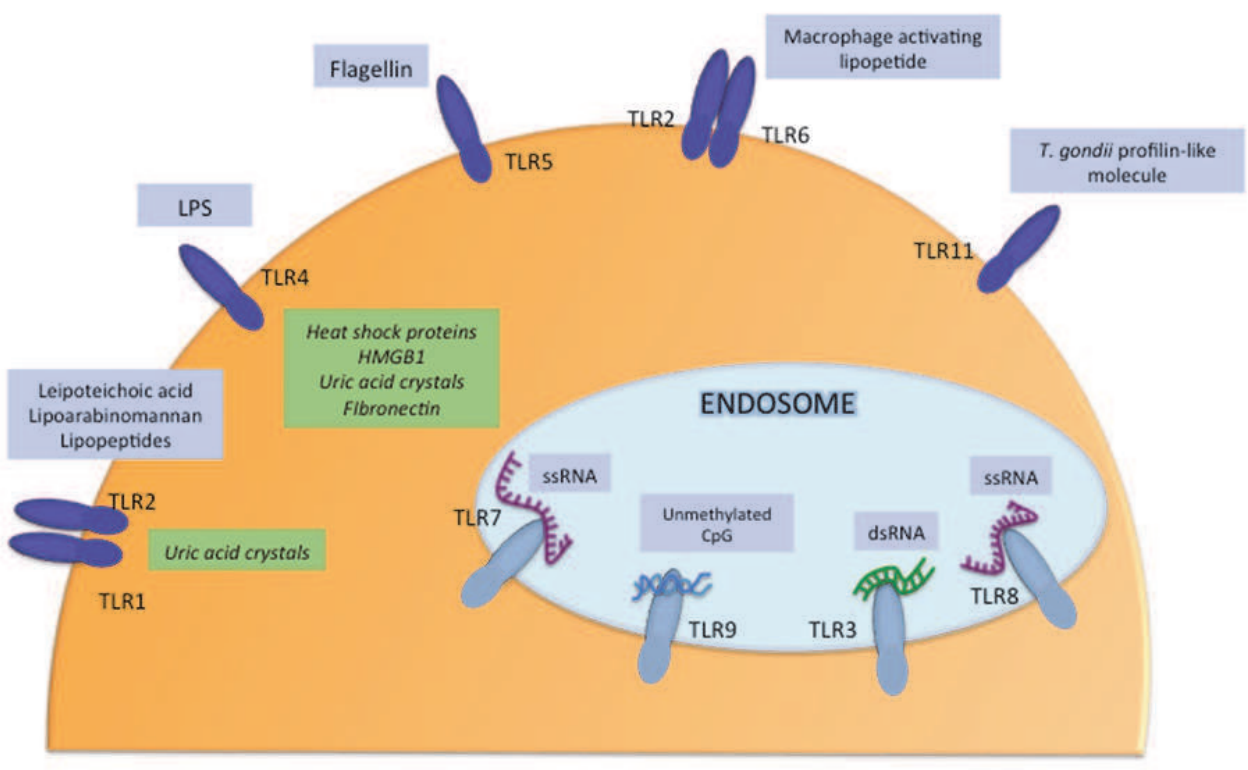

Fig. 2. Overview of toll-like receptors (TLRs) and their ligands. Activation of TLRs can be induced by exogenous microbial-derived ligands (PAMPs) as well as endogenous ligands (DAMPs) which are released from tissues in response to injury and inflammation.

Importantly, DAMP-TLR interactions have also been shown to play a decisive role in shaping anti-tumor immune responses (Apetoh et al., 2007a). Tumor cell death induced by some chemotherapy drugs and ionizing radiation resulted in release of copious amounts of the DAMP high-mobility-group box 1 (HMGB1) that binds to TLR4 expressed by DC and promotes the cross-presentation of tumor-derived antigens to T cells (Apetoh et al., 2007b). The ability of TLR engagement to activate innate immune cells to promote a defense response by inducing adaptive anti-tumor responses has spurred efforts to exploit TLR agonists as novel adjuvants for cancer therapy (Adams, 2009). Both purified natural and synthetic TLR ligands have been used in a variety of vaccination regimens designed to 
overcome tolerance and sustain tumor-specific T-cell responses. Evidence from pre-clinical and clinical studies has shown the benefit of TLR stimulation when combined with conventional cancer treatment modalities such as radiotherapy and/or chemotherapy (Manegold et al., 2008; Mason et al., 2006). The discovery that many epithelial cells, including carcinoma cells, do express at least some TLRs, however, has raised the question about the effect of TLR stimulation on the tumor cells (Yu and Chen, 2008), and the effects of their therapeutic use (Huang et al., 2008). For instance, data from both mouse and human cancer cells show that while activation of some TLRs can increase susceptibility of tumor cells to apoptosis (Salaun et al., 2006), the ligation of other TLRs promotes tumorigenesis on several levels. Indeed, in a variety of tumor models, TLR stimulation has been shown to enhance proliferation, diminish tumor susceptibility to apoptosis, stimulate migratory capacity and invasiveness as well as promote angiogenesis (Harmey et al., 2002; Jego et al., 2006; Pidgeon et al., 1999). In the following section, we summarize data about the function of the main TLRs known to be expressed by breast cancer cells.

\subsection{TLR3}

Several TLRs (TLR 3,7,8 and 9) that recognize nucleic acid ligands are expressed intracellularly in the endosomal compartment, thus allowing for rapid detection of foreign nucleic acid material (Liu et al., 2008). TLR3 is an important detector of viral infection since it binds viral double-stranded RNA (dsRNA) and initiates a strong IFN type I response. Synthetic dsRNA agonists for TLR3, such as polyadenylic-polyuridylic acid [poly(A:U)], have been developed and tested in clinical trials in several cancers, including breast cancer, with encouraging results (Lacour et al., 1980). Interestingly, TLR3 is expressed by breast cancer cells and its triggering promotes apoptosis (Salaun et al., 2006) (Figure 3). In a recent clinical trial, adjuvant treatment with poly(A:U) showed a significant decrease in the risk of metastatic relapse in TLR3 positive but not in TLR3negative breast cancers, suggesting that the direct anti-tumor effect may be more important than the indirect stimulation of anti-tumor immunity (Salaun et al., 2011). TLR3 triggering can also elicit the production by some tumor cells of chemokines that recruit immune cells with opposing effects (Conforti et al., 2010). Therefore, the use of TLR3 agonists should be combined with strategies to enhance anti-tumor Th1 responses and/or decrease immunosuppressive cells responsive to CCL5.

\subsection{TLR4}

The prototypical and best-characterized agonist for TLR4 activation is lipopolysaccharide (LPS), a structural component of Gram-negative bacteria. TLR4 can also be stimulated by viral components derived, for example, from respiratory syncytial virus (Kurt-Jones et al., 2000) or the murine retrovirus MMTV (Rassa et al., 2002). Additionally, endogenous DAMPs such as heat-shock proteins and HMGB-1 are ligands for TLR4 (Apetoh et al., 2007b; Ohashi et al., 2000). A synthetic derivative, i.e., monophospohryl lipid A (MPL), is used as a vaccine adjuvant for hepatitis B (Fendrix) and human papilloma virus (Cervarix) (reviewed in (Adams, 2009)). In the 1990's, MPL was included as a component of DETOX adjuvant in tumor vaccines for skin, lung and breast malignancies, with promising results in Phase II/III clinical trials (Eton et al., 1998; He et al., 2007; MacLean et al., 1993). On the other hand, recent evidence has implicated TLR4 expression in tumor cells as having a profound impact on tumor cell survival by evading host anti-tumor responses (He et al., 2007) or promoting 


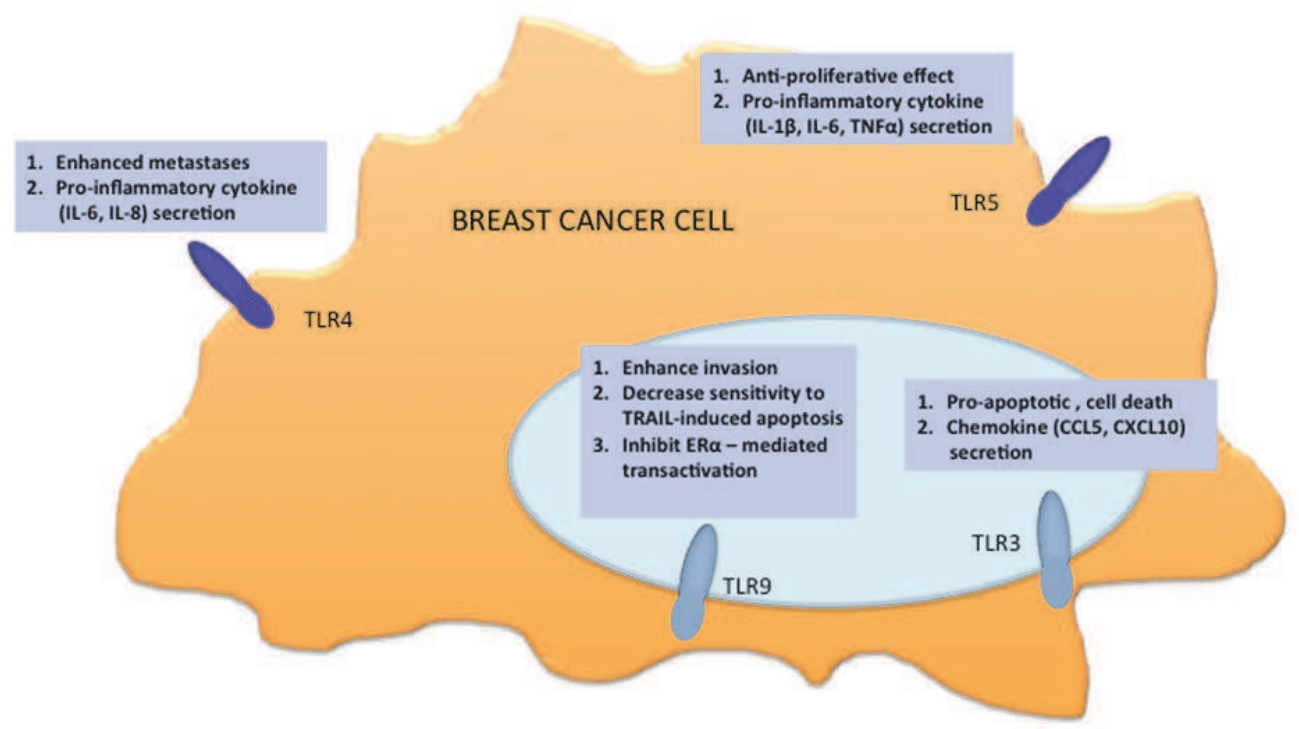

Fig. 3. Documented effects of TLR ligation on breast cancer cells. TLR activation in breast cancer cells is complex since it can either promote tumor cell death or enhance its growth and invasive potential. Like most other epithelial malignancies, breast cancer cells express several TLRs although the endogenous ligands for many of these TLRs remain unknown.

chemoresistance (Kelly et al., 2006). Expression of TLR4 by a large majority ( $90 \%)$ of primary breast cancers was detected by immunohistochemistry in a study of 133 cases, but there was no significant association between TLR4-positivity and outcome (Petricevic et al., 2011). On the other hand, another study reported an interesting correlation between metastatic propensity and expression of TLR4 among stromal cells (i.e mononuclear inflammatory cells), which are found in abundance in primary breast tumors (GonzalezReyes et al., 2010). These findings reiterate the complexity of the role that stromal cells play in tumor progression and suggest that TLR4 expression may be a critical mediator in these events. Furthermore, TLR4 was the predominant TLR detected in the immortalized human breast cancer cell line MDA-MB-231 (Yang et al., 2010). Knockdown of TLR4 significantly inhibited growth and secretion of IL- 6 and IL- 8 by these breast cancer cells, suggesting that TLR4 could be a therapeutic target. Overall, while stimulation of TLR4 in the cancer cells themselves may have deleterious effects, stimulation of TLR4 in innate immune cells could have opposite effects, depending on the tumor microenvironment, the type of myeloid cells involved (e.g., macrophages versus DC) and the availability of other signals that have to be integrated by DC to promote, rather than suppress, anti-tumor immune responses (Zitvogel et al., 2010).

\subsection{TLR5}

TLR5 is a cell surface receptor that recognizes bacterial flagellin and is unique among TLRs in that it is highly expressed in DCs within the lamina propria of the gut epithelium. It has also been detected in carcinomas of the gastro-intestinal tract, where it has been hypothesized that it may interact with bacterial pathogens linked to cancer development 
such as Helicobacter pylori (Schmausser et al., 2005). Interestingly, a functional TLR5 is also expressed by human prostate cancer cells and its stimulation triggers the production of chemokines that recruit immune cells, although it is unclear whether recruited cells contribute to pro-tumorigenic inflammation or tumor rejection (Galli et al., 2010). On the other hand, the pro-inflammatory effects of TLR5 activation, particularly IL-6 and CCL2 release, were implicated in tumor progression of ovarian malignancies (Zhou et al., 2009). Indeed, early studies comparing TLR5 expression in normal and ovarian cancer have suggested that TLR5 could be a promising biomarker for malignant changes (Kim et al., 2008).

In a preclinical model of breast cancer, administration of flagellin to mice with established tumors inhibited the growth of an immunogenic variant expressing human Her-2 but not the parental non-immunogenic tumor (Sfondrini et al., 2006). TLR5 stimulation by flagellin was associated with enhanced IFN $\gamma$ production and diminished infiltration of Treg cells. Interestingly, flagellin treatment at the time of tumor implantation had the opposite effect, leading to decreased IFN $\gamma$, increased frequency of Treg cells and accelerated tumor growth, indicating that opposing effects may be elicited depending on the tumor/host environment at time of administration (Sfondrini et al., 2006). However, since TLR5 expression in tumor cells themselves was not definitively established, no conclusions could be drawn whether the pro- or anti-tumorigenic effects of flagellin treatment resulted from direct effects on carcinoma cells.

A recent study in human primary breast cancer specimens from 75 patients demonstrated that TLR5 is expressed in normal ductal epithelium and in $80 \%$ of breast cancers examined (Cai et al., 2011). TLR5 was also expressed in 6 human breast cancer cell lines, and flagellin treatment inhibited tumor cell proliferation in vitro and in vivo, in a xenograft model. In MCF7 cells, flagellin stimulation induced tumor necrosis factor (TNF)- $\alpha$, IL-1 $\beta$, IL-6, and IL-8 mRNA, suggesting that flagellin activates TLR5-dependent signaling pathway in breast cancer cells. The production of several chemokines was also increased by flagellin, including MIP-3 $\alpha$, MCP-1, macrophage-derived chemokine (MDC), IL-6, Gro$\alpha$, and osteoprotegerin. In vivo, flagellin-treated MCF7 and MDA-MB-468 tumors growing in nude ( $\mathrm{T}$ cell deficient) mice showed increased infiltration by neutrophils (Cai et al., 2011). It will be important to establish, however, if these anti-tumor effects can be achieved in immunocompetent mice.

\subsection{TLR9}

TLR9 is located intracellularly in the endoplasmic reticulum and binding induces translocation to the endosomal/lysosomal compartment. In humans, TLR9 is abundantly expressed in plasmacytoid DC (pDCs) and B cells. Until recently, TLR9 has been thought to recognize hypomethylated $\mathrm{CpG}$ deoxynucleotides (CpG-ODN) motifs characteristic of bacterial DNA but molecular studies have definitively shown that TLR9 binds instead to the 2'-deoxyribose sugar backbone (Haas et al., 2008). TLR9 activation in pDC enhances their maturation into more efficient antigen presenting cells and producers of powerful proinflammatory cytokines such as type I IFN (Gilliet et al., 2008). Furthermore, the activation of TLR9 in B cells promotes their proliferation and polyclonal immunoglobulin synthesis, thus generating a robust humoral response as well (Chiron et al., 2008). The broad spectrum of immunoactivating effects of TLR9 stimulation on both innate and adaptive responses have spurred efforts to use synthetic TLR9 ligands as an immunotherapeutic for both solid 
tumors and hematological malignancies (Krieg, 2008). Initially, TLR9 expression was thought to be restricted to immune cells, but recent studies have conclusively showed that a variety of tumor cell types also express functional TLR9 molecules. Indeed, expression of TLR9 has been confirmed in both frozen breast tumor specimens (Berger et al., 2010)as well as breast cancer cell lines (Berger et al., 2010; Merrell et al., 2006; Qiu et al., 2009). A study of 124 frozen breast tissue specimen from women diagnosed with breast cancer found a positive correlation (Spearman rank $p=0.04$ ) between TLR9 mRNA expression and increasing tumor grade, suggesting that TLR9 expression may be a molecular marker for poorly differentiated breast cancers (Berger et al., 2010).

The direct effects of TLR9 stimulation on tumor cells, however, remains decidedly complex. In 2006, Selander and colleagues showed that CpG-ODN stimulation of the TLR9positive MDA-MB-231 but not TLR9-negative MCF-7 human breast cancer cells induced their migration across a matrigel matrix (Merrell et al., 2006), suggesting that TLR9 signaling plays a role in cancer progression and metastasis. TLR9 overexpression in BT-20 breast cancer cells has similarly been found to enhance invasiveness in vitro (Berger et al., 2010). In both studies, CpG-ODN stimulation did not affect cellular proliferation, thus negating the possibility that the enhanced migration could be attributed to increased cell division. TLR9 expression may also be a mechanism that tumors employ to evade host immune responses such as tumor necrosis factor-related apoptosis inducing ligand (TRAIL)-induced apoptosis. The TRAIL/TRAIL receptor interaction is an important mechanism by which anti-tumor effectors such as CD8 T cells, NK cells and NKT cells mediate tumor-directed cell kill. In an in vitro study using TLR9-expressing breast cancer cell lines HCC1569 and Cal51, CpG-ODN stimulation resulted in a significant decrease in the sensitivity of tumor cells to lexatumumab, an anti-DR5 agonist antibody that stimulates the TRAIL pathway (Chiron et al., 2009; Ohta et al., 2006) . Using a synthetic TLR9 ligand in which the phosphate backbone was modified to increase resistance to nucleases and enhance circulating half-life, Chiron and co-workers showed that the phosphorothioatemodified TLR9 agonist could bind directly to the DR5 receptor on tumor cells and inhibit TRAIL-dependent killing by NK cells. These findings have important implications for the use of TLR9-directed therapies using synthetic CpG-ODNs which may potentially attenuate tumor immunosurveillance. Conversely, a recent study suggest that CpG-ODN stimulation may hold therapeutic promise in estrogen-responsive breast cancer cells (Qiu et al., 2009). TLR9 activation in T47D and MCF-7 breast cancer cells inhibited estrogenreceptor alpha $(\mathrm{ER} \alpha)$-mediated transactivation through the NF- $\kappa \mathrm{B}$ pathway. Although these findings need to be confirmed in primary breast tumor tissues, it is intriguing to investigate whether CPG-ODN stimulation can synergize with hormonal therapy for $\mathrm{ER}^{+}$ breast cancers.

\section{The cross-talk between regulatory T cells and breast cancer cells (RANKL)}

Receptor activator of NF-kB (RANK) is a type I membrane protein, which shares high homology with CD40. RANK ligand (RANKL, also called TRANCE (TNF-related activationinduced cytokine) or osteoclast differentiation factor (ODF) is a type II membrane protein with belongs to the TNF superfamily originally identified as a dendritic cell survival factor. RANKL is predominately expressed in activated T cells, as well as the thymus, lymph node and bone marrow. RANK/RANKL are essential regulators of bone remodeling, body temperature, lymph node and thymus formation as well as mammary gland development 
during pregnancy (Leibbrandt and Penninger, 2008). Furthermore, the RANK/RANKL axis has been linked to progestin-driven breast carcinomas and bone metastases (Schramek et al., 2010).

In addition to the expression of RANK on hematopoietic osteoclast precursors and DC, the receptor is also expressed by some tumor cell types, including melanoma, osteosarcomas, breast and prostate cancers (Jones et al., 2006; Mori et al., 2007a; Mori et al., 2007b). RANK expression has been reported in $6-57 \%$ of invasive human breast cancers, depending upon the parameters used to define positivity and antibodies utilized for staining (GonzalezSuarez et al., 2010; Santini et al., 2011). Stimulation of RANK+ human breast cancer cells with recombinant RANKL induces actin polymerization and migration without affecting cell proliferation (Jones et al., 2006). Preclinical models of Her-2+ mammary carcinoma (MMTV-neu transgenic mouse) have shown that metastatic spread is dependent on RANK signaling and that pharmacological inhibition of RANKL reduces tumor growth and lung metastases (Gonzalez-Suarez et al., 2010; Tan et al., 2011).

While only a subgroup of breast cancers expresses RANKL and there is no evidence for colocalization of RANK and its ligand in the carcinoma epithelium (Gonzalez-Suarez et al., 2010; Van Poznak et al., 2006), RANKL is expressed by infiltrating immune cells. In one study, RANKL was detected in tumor-infiltrating mononuclear cells (not further characterized) and occasionally in fibroblast-like stromal cells (Gonzalez-Suarez et al., 2010). Another report showed that the majority of RANKL-producing cells infiltrating breast cancers were T cells expressing FOXP3, a transcription factor produced by Treg cells (Tan et al., 2011). Importantly, RANK signaling mediated the metastatic behavior of RANKexpressing mouse breast cancer cells, and RANKL was produced by Treg cells (Tan et al., 2011). Therefore, in addition to suppressing anti-tumor immune responses, Treg cells might promote the metastatic behaviors of some tumors by producing RANKL, explaining why Treg cells have been shown to have prognostic significance in breast cancers. In 237 patients with operable breast cancers, Treg cell numbers in the primary tumor correlated with relapse-free survival independently of nodal involvement, tumor size and grade (Bates et al., 2006). Therefore, it will be of great interest to determine if tumor infiltration by Treg cells and/or Th17 cells, another $\mathrm{T}$ cell subset that has been shown to express high levels of RANKL (Sato et al., 2006), predicts for increased metastases of RANK+ breast cancers, and whether RANKL inhibition will be effective at inhibiting metastasis and risk of recurrence and death from breast cancer.

\section{Therapeutic implications}

The role of interactions between tumor cells and host immune system is increasingly appreciated as critical for tumor development and progression, as well as therapeutic response. As discussed above, the type and density of immune cells infiltrating breast cancers is associated with prognosis, with high density of macrophages forecasting a worse outcome (Bingle et al., 2002) while high numbers of $\mathrm{CD} 8^{+} \mathrm{T}$ cells predict a better outcome (Mahmoud et al., 2011). Importantly, the presence of a brisk lymphocytic infiltrate in pretreatment biopsies of more than one thousand primary breast cancers was significantly associated with pathological complete response ( $\mathrm{PCR}$ ) to neoadjuvant anthracycline/taxane treatment (Denkert et al., 2010). A significant association was found between markers of $\mathrm{T}$ cells (CD3) and effector T-cell recruitment (CXCL9) and pCR (Denkert et al., 2010). These data in patients support the concept that the anti-cancer immune response is essential for 
therapeutic success (Zitvogel et al., 2008), and suggest that immune infiltrates can provide predictive information. Indeed, if cytocidal treatments work, in part, by causing an immunogenic tumor cell death and generating an in situ vaccine, the presence of a less immunosuppressive microenvironment will favor development of anti-tumor immunity post-treatment (Apetoh et al., 2007c; Formenti and Demaria, 2009; Ghiringhelli et al., 2009; Obeid et al., 2007). Conversely, immune cells and their receptors become attractive targets for improving response to chemo- and radio-therapy. For example, we have shown in a mouse model of metastatic breast cancer that targeting the co-inhibitory receptor CTLA- 4 on $\mathrm{T}$ cells synergizes with local radiotherapy in inducing the immune-mediated regression of the irradiated tumor and metastases outside of the radiation field (Demaria et al., 2005). In a different mouse model of breast cancer targeting colony stimulating factor (CSF)- 1 receptor with an antagonist blocked macrophage recruitment to paclitaxel-treated tumors leading to improved therapeutic response, longer survival and reduced metastases (DeNardo et al., 2011).

Strategies to deplete Treg cells in breast cancer patients (Dannull et al., 2005; Rech and Vonderheide, 2009) may also be beneficial by reducing local immunosuppression as well as removing a main source of RANKL production. Increased accumulation of Treg cells is also seen in sentinel lymph nodes of breast cancer patients and it correlates with the size of the primary tumor (Gupta et al., 2011). Since anti-tumor T cells are activated in sentinel lymph nodes (Kim et al., 2006) the increased Treg cell presence might limit the efficacy of preoperative chemotherapy for locally advanced breast cancer by inhibiting the activation of tumor-specific T cells (Boissonnas et al., 2010).

Multiple additional strategies for manipulating the immune environment of breast cancer are being studied, including TLR agonists (Lu et al., 2010), immunomodulatory drugs and vaccines (Emens et al., 2009). A critical question that will need to be addressed is how we predict response to treatment with agents that target the immune system, whether directly such as antibodies against co-stimulatory or co-inhibitory $\mathrm{T}$ cell receptors, or indirectly such as chemotherapy drugs that induce an immunogenic cell death. In fact, polymorphisms of TLR4 and P2X7, receptors that play a key role in development of anti-tumor immunity following chemotherapy-induced immunogenic tumor cell death, are present in the population and have been shown to impact response to treatment with anthracyclines and radiotherapy (Apetoh et al., 2007c; Ghiringhelli et al., 2009). Therefore, as recently proposed by Zitvogel and colleagues (Zitvogel et al., 2011), immune-relevant biomarkers will need to be considered together with tumor cell biomarkers in tailoring treatment for patients towards a personalized therapeutic approach.

\section{Conclusions}

This chapter summarizes the recent advances in our understanding of the interplay between breast cancer and the immune system. Cancer cells secrete and respond to cytokines, chemokines, and DAMPs influencing the nature and quantity of the immune infiltrate. In turn, the type of immune cells present within breast cancer can have a major impact on tumor progression, prognosis and response to treatment. Immune cells can foster a protumorigenic inflammatory environment as well as inhibit tumors (Figure 4). To achieve therapeutic success, any treatment strategy will need to include an approach to shift the balance of pro-tumorigenic and anti-tumor immunity in favor of the latter. The good news is that enlisting the power of the immune system to synergize with cytocidal tumor therapy 
holds the promise to revolutionize treatment and the hope to achieve long-term tumor control and perhaps cure (Schreiber et al., 2011).

\section{TUMOR PROMOTION}

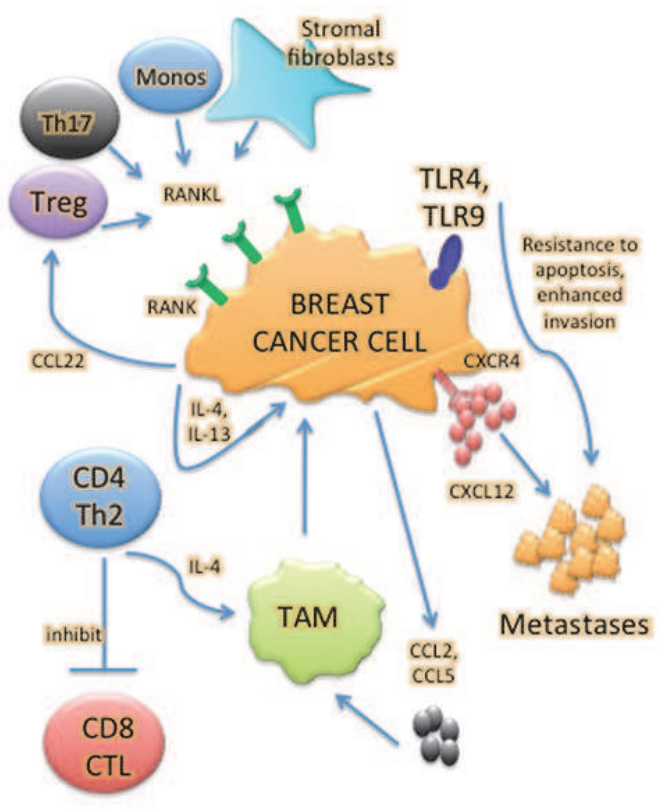

TUMOR INHIBITION

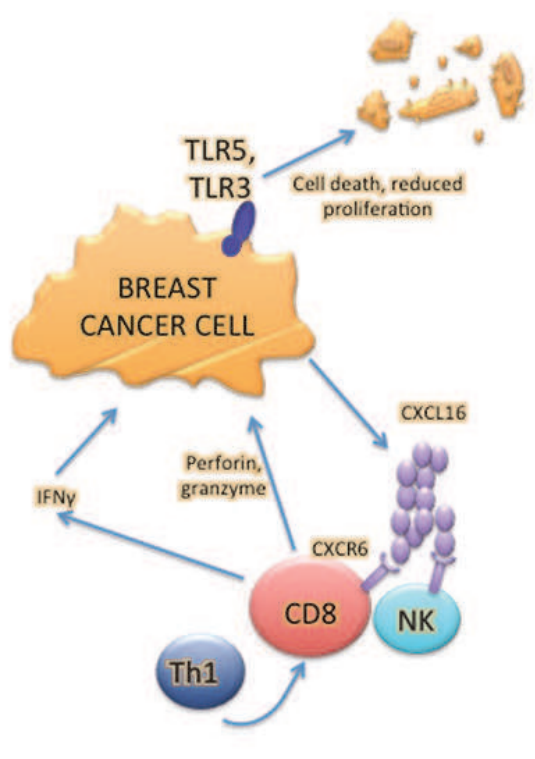

Fig. 4. Immune cells infiltrating breast cancer play a dual role, promoting (left) or inhibiting (right) tumor growth and metastases. Breast cancer cells produce chemokines, such as CCL5 and MCP-1, that recruit monocytic cells which, in the presence of IL-4 secreted by Th2 T cells differentiate into pro-tumorigenic macrophages (TAMs). Breast cancer cells also express chemokine receptors, such as CXCR4, that promote their migration in response to CXCL12, guiding metastases to distant organs. In contrast, other chemokines produced by breast cancer cells, such as CXCL16, promote the recruitment of CXCR6+ anti-tumor CD8 T cells. Activation of TLRs on the surface of breast cancer cells has differential effects that can either promote or inhibit tumor growth. The recruitment of Treg cells by breast tumor cells via secretion of CCL22 contributes to create an immunosuppressive milieu. In addition, RANKL production by Treg and Th17 cells, and possibly other stromal cells, promotes metastases of RANK+ breast cancer cells.

\section{Acknowledgments}

Sandra Demaria is supported, in part, by NIH R01 CA113851 and a grant from the Chemotherapy Foundation. Karsten A. Pilones is supported by DOD BCRP Post-doctoral fellowship W81XWH-10-1-0007. Sylvia Adams is supported, in part, by NCI K23 CA125205. 


\section{References}

Abel, S., Hundhausen, C., Mentlein, R., Schulte, A., Berkhout, T.A., Broadway, N., Hartmann, D., Sedlacek, R., Dietrich, S., Muetze, B., Schuster, B., Kallen, K.J., Saftig, P., Rose-John, S., \&Ludwig, A.(2004) The transmembrane CXC-chemokine ligand 16 is induced by IFN-gamma and TNF-alpha and shed by the activity of the disintegrin-like metalloproteinase ADAM10. J Immunol. Vol. 172:pp6362-6372.

Adams, S.(2009) Toll-like receptor agonists in cancer therapy. Immunotherapy. Vol. 1:pp949964.

Allavena, P., Sica, A., Garlanda, C., \&Mantovani, A.(2008) The Yin-Yang of tumor-associated macrophages in neoplastic progression and immune surveillance. Immunol Rev. Vol. 222:pp155-161.

Apetoh, L., Ghiringhelli, F., Tesniere, A., Criollo, A., Ortiz, C., Lidereau, R., Mariette, C., Chaput, N., Mira, J.-P., Delaloge, S., Andre, F., Tursz, T., Kroemer, G., \&Zitvogel, L.(2007a) The interaction between HMGB1 and TLR4 dictates the outcome of anticancer chemotherapy and radiotherapy. Immunological Reviews. Vol. 220:pp4759.

Apetoh, L., Ghiringhelli, F., Tesniere, A., Obeid, M., Ortiz, C., Criollo, A., Mignot, G., Maiuri, M.C., Ullrich, E., Saulnier, P., Yang, H., Amigorena, S., Ryffel, B., Barrat, F.J., Saftig, P., Levi, F., Lidereau, R., Nogues, C., Mira, J.-P., Chompret, A., Joulin, V., ClavelChapelon, F., Bourhis, J., Andre, F., Delaloge, S., Tursz, T., Kroemer, G., \&Zitvogel, L.(2007b) Toll-like receptor 4-dependent contribution of the immune system to anticancer chemotherapy and radiotherapy. Nat Med. Vol. 13:pp1050-1059.

Apetoh, L., Ghiringhelli, F., Tesniere, A., Obeid, M., Ortiz, C., Criollo, A., Mignot, G., Maiuri, M.C., Ullrich, E., Saulnier, P., Yang, H., Amigorena, S., Ryffel, B., Barrat, F.J., Saftig, P., Levi, F., Lidereau, R., Nogues, C., Mira, J.P., Chompret, A., Joulin, V., ClavelChapelon, F., Bourhis, J., André, F., Delaloge, S., Tursz, T., Kroemer, G., \&Zitvogel, L.(2007c) Toll-like receptor 4-dependent contribution of the immune system to anticancer chemotherapy and radiotherapy. Nat Med. Vol. 13:pp1050-1059.

Aspord, C., Pedroza-Gonzalez, A., Gallegos, M., Tindle, S., Burton, E.C., Su, D., Marches, F., Banchereau, J., \&Palucka, A.K.(2007) Breast cancer instructs dendritic cells to prime interleukin 13-secreting CD4+ T cells that facilitate tumor development. J Exp Med. Vol. 204:pp1037-1047.

Balkwill, F.(2004) Cancer and the chemokine network. Nat Rev Cancer. Vol. 4:pp540-550.

Barcellos-Hoff, M.H., \&Akhurst, R.J.(2009) Transforming growth factor-beta in breast cancer: too much, too late. Breast Cancer Res. Vol. 11:pp202.

Barton, G.M., \&Medzhitov, R.(2002) Toll-like receptors and their ligands. Current Topics in Microbiology \& Immunology. Vol. 270:pp81-92.

Bates, G.J., Fox, S.B., Han, C., Leek, R.D., Garcia, J.F., Harris, A.L., \&Banham, A.H.(2006) Quantification of regulatory $\mathrm{T}$ cells enables the identification of high-risk breast cancer patients and those at risk of late relapse. J Clin Oncol. Vol. 24:pp5373-5380.

Bell, D., Chomarat, P., Broyles, D., Netto, G., Harb, G.M., Lebecque, S., Valladeau, J., Davoust, J., Palucka, K.A., \&Banchereau, J.(1999) In breast carcinoma tissue, immature dendritic cells reside within the tumor, whereas mature dendritic cells are located in peritumoral areas. J Exp Med. Vol. 190:pp1417-1426. 
Berger, R., Fiegl, H., Goebel, G., Obexer, P., Ausserlechner, M., Doppler, W., HauserKronberger, C., Reitsamer, R., Egle, D., Reimer, D., Muller-Holzner, E., Jones, A., \&Widschwendter, M.(2010) Toll-like receptor 9 expression in breast and ovarian cancer is associated with poorly differentiated tumors. Cancer Science. Vol. 101:pp1059-1066.

Bianchi, M.E.(2007) DAMPs, PAMPs and alarmins: all we need to know about danger. J Leukoc Biol. Vol. 81:pp1-5.

Bingle, L., Brown, N.J., \&Lewis, C.E.(2002) The role of tumour-associated macrophages in tumour progression: implications for new anticancer therapies. J Pathol. Vol. 196:pp254-265.

Boissonnas, A., Scholer-Dahirel, A., Simon-Blancal, V., Pace, L., Valet, F., Kissenpfennig, A., Sparwasser, T., Malissen, B., Fetler, L., \&Amigorena, S.(2010) Foxp3+ T cells induce perforin-dependent dendritic cell death in tumor-draining lymph nodes. Immunity. Vol. 32:pp266-278.

Cai, Z., Sanchez, A., Shi, Z., Zhang, T., Liu, M., \&Zhang, D.(2011) Activation of Toll-like Receptor 5 on Breast Cancer Cells by Flagellin Suppresses Cell Proliferation and Tumor Growth. Cancer Research. Vol. 71:pp2466-2475.

Calabrò, A., Beissbarth, T., Kuner, R., Stojanov, M., Benner, A., Asslaber, M., Ploner, F., Zatloukal, K., Samonigg, H., Poustka, A., \&Sültmann, H.(2009) Effects of infiltrating lymphocytes and estrogen receptor on gene expression and prognosis in breast cancer. Breast Cancer Res Treat. Vol. 116:pp69-77.

Chiron, D., Bekeredjian-Ding, I., Pellat-Deceunynck, C., Bataille, R., \&Jego, G.(2008) Toll-like receptors: lessons to learn from normal and malignant human B cells. Blood. Vol. 112:pp2205-2213.

Chiron, D., Pellat-Deceunynck, C., Maillasson, M., Bataille, R., \&Jego, G.(2009) Phosphorothioate-modified TLR9 ligands protect cancer cells against TRAILinduced apoptosis. J Immunol. Vol. 183:pp4371-4377.

Conforti, R., Ma, Y., Morel, Y., Paturel, C., Terme, M., Viaud, S., Ryffel, B., Ferrantini, M., Uppaluri, R., Schreiber, R., Combadiere, C., Chaput, N., Andre, F., Kroemer, G., \&Zitvogel, L.(2010) Opposing effects of toll-like receptor (TLR3) signaling in tumors can be therapeutically uncoupled to optimize the anticancer efficacy of TLR3 ligands. Cancer Research. Vol. 70:pp490-500.

Dannull, J., Su, Z., Rizzieri, D., Yang, B.K., Coleman, D., Yancey, D., Zhang, A., Dahm, P., Chao, N., Gilboa, E., \&Vieweg, J.(2005) Enhancement of vaccine-mediated antitumor immunity in cancer patients after depletion of regulatory T cells. J Clin Invest. Vol. 115:pp3623-3633.

Darash-Yahana, M., Gillespie, J.W., Hewitt, S.M., Chen, Y.Y., Maeda, S., Stein, I., Singh, S.P., Bedolla, R.B., Peled, A., Troyer, D.A., Pikarsky, E., Karin, M., \&Farber, J.M.(2009) The chemokine CXCL16 and its receptor, CXCR6, as markers and promoters of inflammation-associated cancers. PLoS One. Vol. 4:ppe6695.

Demaria, S., Kawashima, N., Yang, A.M., Devitt, M.-L., Babb, J.S., Allison, J.P., \&Formenti, S.C.(2005) Immune-mediated inhibition of metastases following treatment with local radiation and CTLA-4 blockade in a mouse model of breast cancer. Clin Cancer Res. Vol. 11:pp728-734. 
Demaria, S., Pikarsky, E., Karin, M., Coussens, L.M., Chen, Y.C., El-Omar, E.M., Trinchieri, G., Dubinett, S.M., Mao, J.T., Szabo, E., Krieg, A., Weiner, G.J., Fox, B.A., Coukos, G., Wang, E., Abraham, R.T., Carbone, M., \&Lotze, M.T.(2010) Cancer and inflammation: promise for biologic therapy. J Immunother. Vol. 33:pp335-351.

DeNardo, D.G., Barreto, J.B., Andreu, P., Vasquez, L., Tawfik, D., Kolhatkar, N., \&Coussens, L.M.(2009) CD4(+) T cells regulate pulmonary metastasis of mammary carcinomas by enhancing protumor properties of macrophages. Cancer Cell. Vol. 16:pp91-102.

DeNardo, D.G., \&Coussens, L.M.(2007) Inflammation and breast cancer. Balancing immune response: crosstalk between adaptive and innate immune cells during breast cancer progression. Breast Cancer Res. Vol. 9:pp212.

DeNardo, D.G., Donal J. Brennan, D.J., Rexhepaj, E., Ruffell, B., Shiao, S.L., Madden, S.F., Gallagher, W.M., Wadhwani, N., Scott D. Keil, S.D., Junaid, S.A., Rugo, H.S., Hwang, E.S., Jirström, K., West, B.L., \&Coussens, L.M.(2011) Leukocyte Complexity Predicts Breast Cancer Survival and Functionally Regulates Response to Chemotherapy. Cancer Discov. Vol. doi:10.1158/2159-8274.CD-10-0028.

Denkert, C., Loibl, S., Noske, A., Roller, M., Muller, B.M., Komor, M., Budczies, J., DarbEsfahani, S., Kronenwett, R., Hanusch, C., von Torne, C., Weichert, W., Engels, K., Solbach, C., Schrader, I., Dietel, M., \&von Minckwitz, G.(2010) Tumor-associated lymphocytes as an independent predictor of response to neoadjuvant chemotherapy in breast cancer.[Erratum appears in J Clin Oncol. $2010 \mathrm{Feb}$ 1;28(4):708]. Journal of Clinical Oncology. Vol. 28:pp105-113.

Desmedt, C., Haibe-Kains, B., Wirapati, P., Buyse, M., Larsimont, D., Bontempi, G., Delorenzi, M., Piccart, M., \&Sotiriou, C.(2008) Biological processes associated with breast cancer clinical outcome depend on the molecular subtypes. Clin Cancer Res. Vol. 14:pp5158-5165.

Disis, M.L.(2010) Immune regulation of cancer. J Clin Oncol. Vol. 28:pp4531-4538.

Emens, L.A., Asquith, J.M., Leatherman, J.M., Kobrin, B.J., Petrik, S., Laiko, M., Levi, J., Daphtary, M.M., Biedrzycki, B., Wolff, A.C., Stearns, V., Disis, M.L., Ye, X., Piantadosi, S., Fetting, J.H., Davidson, N.E., \&Jaffee, E.M.(2009) Timed sequential treatment with cyclophosphamide, doxorubicin, and an allogeneic granulocytemacrophage colony-stimulating factor-secreting breast tumor vaccine: a chemotherapy dose-ranging factorial study of safety and immune activation. Journal of Clinical Oncology. Vol. 27:pp5911-5918.

Eton, O., Kharkevitch, D.D., Gianan, M.A., Ross, M.I., Itoh, K., Pride, M.W., Donawho, C., Buzaid, A.C., Mansfield, P.F., Lee, J.E., Legha, S.S., Plager, C., Papadopoulos, N.E., Bedikian, A.Y., Benjamin, R.S., \&Balch, C.M.(1998) Active immunotherapy with ultraviolet B-irradiated autologous whole melanoma cells plus DETOX in patients with metastatic melanoma. Clinical Cancer Research. Vol. 4:pp619-627.

Finak, G., Bertos, N., Pepin, F., Sadekova, S., Souleimanova, M., Zhao, H., Chen, H., Omeroglu, G., Meterissian, S., Omeroglu, A., Hallett, M., \&Park, M.(2008) Stromal gene expression predicts clinical outcome in breast cancer. Nat Med. Vol. 14:pp518527.

Formenti, S.C., \&Demaria, S.(2009) Systemic effects of local radiotherapy. Lancet Oncol. Vol. 10:pp718-726. 
Fridlender, Z.G., Sun, J., Kim, S., Kapoor, V., Cheng, G., Ling, L., Worthen, G.S., \&Albelda, S.M.(2009) Polarization of tumor-associated neutrophil phenotype by TGF-beta: "N1" versus "N2" TAN. Cancer Cell. Vol. 16:pp183-194.

Galli, R., Starace, D., Busa, R., Angelini, D.F., Paone, A., De Cesaris, P., Filippini, A., Sette, C., Battistini, L., Ziparo, E., \&Riccioli, A.(2010) TLR stimulation of prostate tumor cells induces chemokine-mediated recruitment of specific immune cell types. Journal of Immunology. Vol. 184:pp6658-6669.

Gallucci, S., Lolkema, M., \&Matzinger, P.(1999) Natural adjuvants: endogenous activators of dendritic cells. Nat Med. Vol. 5:pp1249-1255.

Ghiringhelli, F., Apetoh, L., Tesniere, A., Aymeric, L., Ma, Y., Ortiz, C., Vermaelen, K., Panaretakis, T., Mignot, G., Ullrich, E., Perfettini, J.L., Schlemmer, F., Tasdemir, E., Uhl, M., Génin, P., Civas, A., Ryffel, B., Kanellopoulos, J., Tschopp, J., André, F., Lidereau, R., McLaughlin, N.M., Haynes, N.M., Smyth, M.J., Kroemer, G., \&Zitvogel, L.(2009) Activation of the NLRP3 inflammasome in dendritic cells induces IL-1beta-dependent adaptive immunity against tumors. Nat Med. Vol. 15:pp1170-1178.

Gilliet, M., Cao, W., \&Liu, Y.-J.(2008) Plasmacytoid dendritic cells: sensing nucleic acids in viral infection and autoimmune diseases. Nature Reviews Immunology. Vol. 8:pp594606.

Gobert, M., Treilleux, I., Bendriss-Vermare, N., Bachelot, T., Goddard-Leon, S., Arfi, V., Biota, C., Doffin, A.C., Durand, I., Olive, D., Perez, S., Pasqual, N., Faure, C., RayCoquard, I., Puisieux, A., Caux, C., Blay, J.Y., \&Ménétrier-Caux, C.(2009) Regulatory $\mathrm{T}$ cells recruited through CCL22/CCR4 are selectively activated in lymphoid infiltrates surrounding primary breast tumors and lead to an adverse clinical outcome. Cancer Res. Vol. 69:pp2000-2009.

Goldberg-Bittman, L., Neumark, E., Sagi-Assif, O., Azenshtein, E., Meshel, T., Witz, I.P., \&Ben-Baruch, A.(2004) The expression of the chemokine receptor CXCR3 and its ligand, CXCL10, in human breast adenocarcinoma cell lines. Immunol Lett. Vol. 92:pp171-178.

Gonzalez-Reyes, S., Marin, L., Gonzalez, L., Gonzalez, L.O., del Casar, J.M., Lamelas, M.L., Gonzalez-Quintana, J.M., \&Vizoso, F.J.(2010) Study of TLR3, TLR4 and TLR9 in breast carcinomas and their association with metastasis. BMC Cancer. Vol. 10:pp665.

Gonzalez-Suarez, E., Jacob, A.P., Jones, J., Miller, R., Roudier-Meyer, M.P., Erwert, R., Pinkas, J., Branstetter, D., \&Dougall, W.C.(2010) RANK ligand mediates progestininduced mammary epithelial proliferation and carcinogenesis. Nature. Vol. 468:pp103-107.

Gorelik, L., \&Flavell, R.A.(2001) Immune-mediated eradication of tumors through the blockade of transforming growth factor-beta signaling in T cells. Nat Med. Vol. 7:pp1118-1122.

Gupta, R., Babb, J.S., Singh, B., Chiriboga, L., Liebes, L., Adams, S., \&Demaria, S.(2011) The Numbers of FoxP3+ Lymphocytes in Sentinel Lymph Nodes of Breast Cancer Patients Correlate With Primary Tumor Size but Not Nodal Status. Cancer Invest. Vol. 29:pp419-425. 
Gutwein, P., Schramme, A., Sinke, N., Abdel-Bakky, M.S., Voss, B., Obermüller, N., Doberstein, K., Koziolek, M., Fritzsche, F., Johannsen, M., Jung, K., Schaider, H., Altevogt, P., Ludwig, A., Pfeilschifter, J., \&Kristiansen, G.(2009) Tumoural CXCL16 expression is a novel prognostic marker of longer survival times in renal cell cancer patients. Eur J Cancer. Vol. 45:pp478-489.

Gyorki, D.E., \&Lindeman, G.J.(2008) Macrophages, more than just scavengers: their role in breast development and cancer. ANZ J Surg. Vol. 78:pp432-436.

Haas, T., Metzger, J., Schmitz, F., Heit, A., Muller, T., Latz, E., \&Wagner, H.(2008) The DNA sugar backbone 2' deoxyribose determines toll-like receptor 9 activation. Immunity. Vol. 28:pp315-323.

Hanahan, D., \&Weinberg, R.A.(2011) Hallmarks of cancer: the next generation. Cell. Vol. 144:pp646-674.

Harmey, J.H., Bucana, C.D., Lu, W., Byrne, A.M., McDonnell, S., Lynch, C., Bouchier-Hayes, D., \&Dong, Z.(2002) Lipopolysaccharide-induced metastatic growth is associated with increased angiogenesis, vascular permeability and tumor cell invasion. International Journal of Cancer. Vol. 101:pp415-422.

He, W., Liu, Q., Wang, L., Chen, W., Li, N., \&Cao, X.(2007) TLR4 signaling promotes immune escape of human lung cancer cells by inducing immunosuppressive cytokines and apoptosis resistance. Mol Immunol. Vol. 44:pp2850-2859.

Heckel, M.C., Wolfson, A., Slachta, C.A., Schwarting, R., Salgame, P., Katsetos, C.D., \&Platsoucas, C.D.(2011) Human breast tumor cells express IL-10 and IL-12p40 transcripts and proteins, but do not produce IL-12p70. Cell Immunol. Vol. 266:pp143-153.

Hojo, S., Koizumi, K., Tsuneyama, K., Arita, Y., Cui, Z., Shinohara, K., Minami, T., Hashimoto, I., Nakayama, T., Sakurai, H., Takano, Y., Yoshie, O., Tsukada, K., \&Saiki, I.(2007) High-level expression of chemokine CXCL16 by tumor cells correlates with a good prognosis and increased tumor-infiltrating lymphocytes in colorectal cancer. Cancer Res. Vol. 67:pp4725-4731.

Huang, B., Zhao, J., Unkeless, J.C., Feng, Z.H., \&Xiong, H.(2008) TLR signaling by tumor and immune cells: a double-edged sword. Oncogene. Vol. 27:pp218-224.

Iwasaki, A., \&Medzhitov, R.(2004) Toll-like receptor control of the adaptive immune responses. Nature Immunology. Vol. 5:pp987-995.

Jego, G., Bataille, R., Geffroy-Luseau, A., Descamps, G., \&Pellat-Deceunynck, C.(2006) Pathogen-associated molecular patterns are growth and survival factors for human myeloma cells through Toll-like receptors. Leukemia. Vol. 20:pp1130-1137.

Jones, D.H., Nakashima, T., Sanchez, O.H., Kozieradzki, I., Komarova, S.V., Sarosi, I., Morony, S., Rubin, E., Sarao, R., Hojilla, C.V., Komnenovic, V., Kong, Y.-Y., Schreiber, M., Dixon, S.J., Sims, S.M., Khokha, R., Wada, T., \&Penninger, J.M.(2006) Regulation of cancer cell migration and bone metastasis by RANKL. Nature. Vol. 440:pp692-696.

Karnoub, A.E., Dash, A.B., Vo, A.P., Sullivan, A., Brooks, M.W., Bell, G.W., Richardson, A.L., Polyak, K., Tubo, R., \&Weinberg, R.A.(2007) Mesenchymal stem cells within tumour stroma promote breast cancer metastasis. Nature. Vol. 449:pp557-563. 
Kelly, M.G., Alvero, A.B., Chen, R., Silasi, D.-A., Abrahams, V.M., Chan, S., Visintin, I., Rutherford, T., \&Mor, G.(2006) TLR-4 signaling promotes tumor growth and paclitaxel chemoresistance in ovarian cancer. Cancer Research. Vol. 66:pp3859-3868.

Kim, C.H., Johnston, B., \&Butcher, E.C.(2002) Trafficking machinery of NKT cells: shared and differential chemokine receptor expression among $\mathrm{V}$ alpha $24(+) \mathrm{V}$ beta $11(+)$ NKT cell subsets with distinct cytokine-producing capacity. Blood. Vol. 100:pp1116.

Kim, C.H., Kunkel, E.J., Boisvert, J., Johnston, B., Campbell, J.J., Genovese, M.C., Greenberg, H.B., \&Butcher, E.C.(2001) Bonzo/CXCR6 expression defines type 1-polarized Tcell subsets with extralymphoid tissue homing potential. J Clin Invest. Vol. 107:pp595-601.

Kim, R., Emi, M., Tanabe, K., \&Arihiro, K.(2006) Immunobiology of the sentinel lymph node and its potential role for antitumour immunity. Lancet Oncol. Vol. 7:pp1006-1016.

Kim, W.Y., Lee, J.W., Choi, J.J., Choi, C.H., Kim, T.J., Kim, B.G., Song, S.Y., \&Bae, D.S.(2008) Increased expression of Toll-like receptor 5 during progression of cervical neoplasia. Int J Gynecol Cancer. Vol. 18:pp300-305.

Kobie, J.J., Wu, R.S., Kurt, R.A., Lou, S., Adelman, M.K., Whitesell, L.J., Ramanathapuram, L.V., Arteaga, C.L., \&Akporiave, E.T.(2003) Transforming growth factor beta inhibits the antigen-presenting functions and antitumor activity of dendritic cell vaccines. Cancer Res. Vol. 63:pp1860-1864.

Kopp, E., \&Medzhitov, R.(2003) Recognition of microbial infection by Toll-like receptors. Current Opinion in Immunology. Vol. 15:pp396-401.

Kreike, B., van Kouwenhove, M., Horlings, H., Weigelt, B., Peterse, H., Bartelink, H., \&van de Vijver, M.J.(2007) Gene expression profiling and histopathological characterization of triple-negative/basal-like breast carcinomas. Breast Cancer Res. Vol. 9:ppR65.

Krieg, A.M.(2008) Toll-like receptor 9 (TLR9) agonists in the treatment of cancer. Oncogene. Vol. 27:pp161-167.

Kunkel, E.J., \&Butcher, E.C.(2002) Chemokines and the tissue-specific migration of lymphocytes. Immunity. Vol. 16:pp1-4.

Kurt-Jones, E.A., Popova, L., Kwinn, L., Haynes, L.M., Jones, L.P., Tripp, R.A., Walsh, E.E., Freeman, M.W., Golenbock, D.T., Anderson, L.J., \&Finberg, R.W.(2000) Pattern recognition receptors TLR4 and CD14 mediate response to respiratory syncytial virus. Nature Immunology. Vol. 1:pp398-401.

Lacour, J., Lacour, F., Spira, A., Michelson, M., Petit, J.Y., Delage, G., Sarrazin, D., Contesso, G., \&Viguier, J.(1980) Adjuvant treatment with polyadenylic-polyuridylic acid (Polya.Polyu) in operable breast cancer. Lancet. Vol. 2:pp161-164.

Leibbrandt, A., \&Penninger, J.M.(2008) RANK/RANKL: regulators of immune responses and bone physiology. Ann N Y Acad Sci. Vol. 1143:pp123-150.

Lin, S., Sun, L., Hu, J., Wan, S., Zhao, R., Yuan, S., \&Zhang, L.(2009) Chemokine C-X-C motif receptor 6 contributes to cell migration during hypoxia. Cancer Lett. Vol. 279:pp108117.

Liu, L., Botos, I., Wang, Y., Leonard, J.N., Shiloach, J., Segal, D.M., \&Davies, D.R.(2008) Structural basis of toll-like receptor 3 signaling with double-stranded RNA. Science. Vol. 320:pp379-381. 
Liu-Bryan, R., Scott, P., Sydlaske, A., Rose, D.M., \&Terkeltaub, R.(2005) Innate immunity conferred by Toll-like receptors 2 and 4 and myeloid differentiation factor 88 expression is pivotal to monosodium urate monohydrate crystal-induced inflammation. Arthritis \& Rheumatism. Vol. 52:pp2936-2946.

Lu, H., Wagner, W.M., Gad, E., Yang, Y., Duan, H., Amon, L.M., Van Denend, N., Larson, E.R., Chang, A., Tufvesson, H., \&Disis, M.L.(2010) Treatment failure of a TLR-7 agonist occurs due to self-regulation of acute inflammation and can be overcome by IL-10 blockade. J Immunol. Vol. 184:pp5360-5367.

Luboshits, G., Shina, S., Kaplan, O., Engelberg, S., Nass, D., Lifshitz-Mercer, B., Chaitchik, S., Keydar, I., \&Ben-Baruch, A.(1999) Elevated expression of the CC chemokine regulated on activation, normal $\mathrm{T}$ cell expressed and secreted (RANTES) in advanced breast carcinoma. Cancer Res. Vol. 59:pp4681-4687.

Luster, A.D., \&Leder, P.(1993) IP-10, a -C-X-C- chemokine, elicits a potent thymusdependent antitumor response in vivo. J Exp Med. Vol. 178:pp1057-1065.

Ma, X., Norsworthy, K., Kundu, N., Rodgers, W.H., Gimotty, P.A., Goloubeva, O., Lipsky, M., Li, Y., Holt, D., \&Fulton, A.(2009) CXCR3 expression is associated with poor survival in breast cancer and promotes metastasis in a murine model. Mol Cancer Ther. Vol. 8:pp490-498.

MacLean, G.D., Reddish, M., Koganty, R.R., Wong, T., Gandhi, S., Smolenski, M., Samuel, J., Nabholtz, J.M., \&Longenecker, B.M.(1993) Immunization of breast cancer patients using a synthetic sialyl-Tn glycoconjugate plus Detox adjuvant. Cancer Immunol Immunother. Vol. 36:pp215-222.

Mahmoud, S.M., Paish, E.C., Powe, D.G., Macmillan, R.D., Grainge, M.J., Lee, A.H., Ellis, I.O., \&Green, A.R.(2011) Tumor-Infiltrating CD8+ Lymphocytes Predict Clinical Outcome in Breast Cancer. J Clin Oncol. Vol. 29:pp1949-1955.

Manegold, C., Gravenor, D., Woytowitz, D., Mezger, J., Hirsh, V., Albert, G., Al-Adhami, M., Readett, D., Krieg, A.M., \&Leichman, C.G.(2008) Randomized phase II trial of a toll-like receptor 9 agonist oligodeoxynucleotide, PF-3512676, in combination with first-line taxane plus platinum chemotherapy for advanced-stage non-small-cell lung cancer. Journal of Clinical Oncology. Vol. 26:pp3979-3986.

Mantovani, A., Allavena, P., Sica, A., \&Balkwill, F.(2008) Cancer-related inflammation. Nature. Vol. 454:pp436-444.

Marshak-Rothstein, A.(2006) Toll-like receptors in systemic autoimmune disease. Nature Reviews. Immunology. Vol. 6:pp823-835.

Mason, K.A., Neal, R., Hunter, N., Ariga, H., Ang, K., \&Milas, L.(2006) CpG oligodeoxynucleotides are potent enhancers of radio- and chemoresponses of murine tumors. Radiotherapy \& Oncology. Vol. 80:pp192-198.

Matsumura, S., Wang, B., Kawashima, N., Braunstein, S., Badura, M., Cameron, T.O., Babb, J.S., Schneider, R.J., Formenti, S.C., Dustin, M.L., \&Demaria, S.(2008) Radiationinduced CXCL16 release by breast cancer cells attracts effector T cells. J Immunol. Vol. 181:pp3099-3107.

Merrell, M.A., Ilvesaro, J.M., Lehtonen, N., Sorsa, T., Gehrs, B., Rosenthal, E., Chen, D., Shackley, B., Harris, K.W., \&Selander, K.S.(2006) Toll-like receptor 9 agonists promote cellular invasion by increasing matrix metalloproteinase activity. Molecular Cancer Research: MCR. Vol. 4:pp437-447. 
Mori, K., Le Goff, B., Berreur, M., Riet, A., Moreau, A., Blanchard, F., Chevalier, C., GuisleMarsollier, I., Leger, J., Guicheux, J., Masson, M., Gouin, F., Redini, F., \&Heymann, D.(2007a) Human osteosarcoma cells express functional receptor activator of nuclear factor-kappa B. J Pathol. Vol. 211:pp555-562.

Mori, K., Le Goff, B., Charrier, C., Battaglia, S., Heymann, D., \&Redini, F.(2007b) DU145 human prostate cancer cells express functional receptor activator of NFkappaB: new insights in the prostate cancer bone metastasis process. Bone. Vol. 40:pp981990.

Muller, A., Homey, B., Soto, H., Ge, N., Catron, D., Buchanan, M.E., McClanahan, T., Murphy, E., Yuan, W., Wagner, S.N., Barrera, J.L., Mohar, A., Verastegui, E., \&Zlotnik, A.(2001) Involvement of chemokine receptors in breast cancer metastasis. Nature. Vol. 410:pp50-56.

Nakayama, T., Hieshima, K., Izawa, D., Tatsumi, Y., Kanamaru, A., \&Yoshie, O.(2003) Cutting edge: profile of chemokine receptor expression on human plasma cells accounts for their efficient recruitment to target tissues. J Immunol. Vol. 170:pp11361140.

Nam, J.S., Terabe, M., Kang, M.J., Chae, H., Voong, N., Yang, Y.A., Laurence, A., Michalowska, A., Mamura, M., Lonning, S., Berzofsky, J.A., \&Wakefield, L.M.(2008) Transforming growth factor beta subverts the immune system into directly promoting tumor growth through interleukin-17. Cancer research. Vol. 68:pp3915-3923.

Obeid, M., Tesniere, A., Ghiringhelli, F., Fimia, G.M., Apetoh, L., Perfettini, J.L., Castedo, M., Mignot, G., Panaretakis, T., Casares, N., Metivier, D., Larochette, N., van Endert, P., Ciccosanti, F., Piacentini, M., Zitvogel, L., \&Kroemer, G.(2007) Calreticulin exposure dictates the immunogenicity of cancer cell death. Nat Med. Vol. 13:pp5461.

Ohashi, K., Burkart, V., Flohe, S., \&Kolb, H.(2000) Cutting edge: heat shock protein 60 is a putative endogenous ligand of the toll-like receptor-4 complex. Journal of Immunology. Vol. 164:pp558-561.

Ohta, A., Gorelik, E., Prasad, S.J., Ronchese, F., Lukashev, D., Wong, M.K., Huang, X., Caldwell, S., Liu, K., Smith, P., Chen, J.F., Jackson, E.K., Apasov, S., Abrams, S., \&Sitkovsky, M.(2006) A2A adenosine receptor protects tumors from antitumor T cells. Proc Natl Acad Sci U S A. Vol. 103:pp13132-13137.

Okamura, Y., Watari, M., Jerud, E.S., Young, D.W., Ishizaka, S.T., Rose, J., Chow, J.C., \&Strauss, J.F., 3rd.(2001) The extra domain A of fibronectin activates Toll-like receptor 4. Journal of Biological Chemistry. Vol. 276:pp10229-10233.

Petricevic, B., Vrbanec, D., Jakic-Razumovic, J., Brcic, I., Rabic, D., Badovinac, T., Ozimec, E., \&Bali, V.(2011) Expression of Toll-like receptor 4 and beta 1 integrin in breast cancer. Medical Oncology. Vol.:pp1-9.

Pidgeon, G.P., Harmey, J.H., Kay, E., Da Costa, M., Redmond, H.P., \&Bouchier-Hayes, D.J.(1999) The role of endotoxin/lipopolysaccharide in surgically induced tumour growth in a murine model of metastatic disease. British Journal of Cancer. Vol. 81:pp1311-1317.

Pollard, J.W.(2004) Tumour-educated macrophages promote tumour progression and metastasis. Nat Rev Cancer. Vol. 4:pp71-78. 
Qian, B.Z., Li, J., Zhang, H., Kitamura, T., Zhang, J., Campion, L.R., Kaiser, E.A., Snyder, L.A., \&Pollard, J.W.(2011) CCL2 recruits inflammatory monocytes to facilitate breast-tumour metastasis. Nature. Vol. Jun 8. doi: 10.1038/nature10138. [Epub ahead of print]

Qiu, J., Wang, X., Guo, X., Zhao, C., Wu, X., \&Zhang, Y.(2009) Toll-like receptor 9 agonist inhibits ERalpha-mediated transactivation by activating NF-kappaB in breast cancer cell lines. Oncology Reports. Vol. 22:pp935-941.

Rassa, J.C., Meyers, J.L., Zhang, Y., Kudaravalli, R., \&Ross, S.R.(2002) Murine retroviruses activate B cells via interaction with toll-like receptor 4. Proceedings of the National Academy of Sciences of the United States of America. Vol. 99:pp2281-2286.

Rech, A.J., \&Vonderheide, R.H.(2009) Clinical use of anti-CD25 antibody daclizumab to enhance immune responses to tumor antigen vaccination by targeting regulatory $\mathrm{T}$ cells. Ann N Y Acad Sci. Vol. 1174:pp99-106.

Roelofs, M.F., Boelens, W.C., Joosten, L.A.B., Abdollahi-Roodsaz, S., Geurts, J., Wunderink, L.U., Schreurs, B.W., van den Berg, W.B., \&Radstake, T.R.D.J.(2006) Identification of small heat shock protein B8 (HSP22) as a novel TLR4 ligand and potential involvement in the pathogenesis of rheumatoid arthritis. Journal of Immunology. Vol. 176:pp7021-7027.

Saji, H., Koike, M., Yamori, T., Saji, S., Seiki, M., Matsushima, K., \&Toi, M.(2001) Significant correlation of monocyte chemoattractant protein-1 expression with neovascularization and progression of breast carcinoma. Cancer. Vol. 92:pp10851091.

Salaun, B., Coste, I., Rissoan, M.-C., Lebecque, S.J., \&Renno, T.(2006) TLR3 can directly trigger apoptosis in human cancer cells. Journal of Immunology. Vol. 176:pp48944901.

Salaun, B., Zitvogel, L., Asselin-Paturel, C., Morel, Y., Chemin, K., Dubois, C., Massacrier, C., Conforti, R., Chenard, M.P., Sabourin, J.-C., Goubar, A., Lebecque, S., Pierres, M., Rimoldi, D., Romero, P., \&Andre, F.(2011) TLR3 as a biomarker for the therapeutic efficacy of double-stranded RNA in breast cancer. Cancer Research. Vol. 71:pp16071614.

Santini, D., Perrone, G., Roato, I., Godio, L., Pantano, F., Grasso, D., Russo, A., Vincenzi, B., Fratto, M.E., Sabbatini, R., Della Pepa, C., Porta, C., Del Conte, A., Schiavon, G., Berruti, A., Tomasino, R.M., Papotti, M., Papapietro, N., Onetti Muda, A., Denaro, V., \&Tonini, G.(2011) Expression pattern of receptor activator of NFkappaB (RANK) in a series of primary solid tumors and related bone metastases. J Cell Physiol. Vol. 226:pp780-784.

Sato, K., Suematsu, A., Okamoto, K., Yamaguchi, A., Morishita, Y., Kadono, Y., Tanaka, S., Kodama, T., Akira, S., Iwakura, Y., Cua, D.J., \&Takayanagi, H.(2006) Th17 functions as an osteoclastogenic helper $\mathrm{T}$ cell subset that links $\mathrm{T}$ cell activation and bone destruction. Journal of Experimental Medicine. Vol. 203:pp2673-2682.

Sato, T., Thorlacius, H., Johnston, B., Staton, T.L., Xiang, W., Littman, D.R., \&Butcher, E.C.(2005) Role for CXCR6 in recruitment of activated CD8+ lymphocytes to inflamed liver. J Immunol. Vol. 174:pp277-283.

Schmausser, B., Andrulis, M., Endrich, S., Muller-Hermelink, H.-K., \&Eck, M.(2005) Toll-like receptors TLR4, TLR5 and TLR9 on gastric carcinoma cells: an implication for 
interaction with Helicobacter pylori. Ijmm International Journal of Medical Microbiology. Vol. 295:pp179-185.

Schramek, D., Leibbrandt, A., Sigl, V., Kenner, L., Pospisilik, J.A., Lee, H.J., Hanada, R., Joshi, P.A., Aliprantis, A., Glimcher, L., Pasparakis, M., Khokha, R., Ormandy, C.J., Widschwendter, M., Schett, G., \&Penninger, J.M.(2010) Osteoclast differentiation factor RANKL controls development of progestin-driven mammary cancer. Nature. Vol. 468:pp98-102.

Schreiber, R.D., Old, L.J., \&Smyth, M.J.(2011) Cancer immunoediting: integrating immunity's roles in cancer suppression and promotion. Science. Vol. 331:pp15651570 .

Sfondrini, L., Rossini, A., Besusso, D., Merlo, A., Tagliabue, E., Menard, S., \&Balsari, A.(2006) Antitumor activity of the TLR-5 ligand flagellin in mouse models of cancer. Journal of Immunology. Vol. 176:pp6624-6630.

Shimaoka, T., nakayama, T., Kume, N., Takahashi, S., Yamaguchi, J., Minami, M., Hayashida, K., Kita, T., Ohsumi, J., Yoshie, O., \&Yonehara, S.(2003) Cutting edge: SR-PSOX/CXC chemokine ligand 16 mediates bacterial phagocytosis by APCs through its chemokine domain. J Immunol. Vol. 171:pp1647-1651.

Soria, G., Yaal-Hahoshen, N., Azenshtein, E., Shina, S., Leider-Trejo, L., Ryvo, L., CohenHillel, E., Shtabsky, A., Ehrlich, M., Meshel, T., Keydar, I., \&Ben-Baruch, A.(2008) Concomitant expression of the chemokines RANTES and MCP-1 in human breast cancer: a basis for tumor-promoting interactions. Cytokine. Vol. 44:pp191-200.

Tan, W., Zhang, W., Strasner, A., Grivennikov, S., Cheng, J.Q., Hoffman, R.M., \&Karin, M.(2011) Tumour-infiltrating regulatory $\mathrm{T}$ cells stimulate mammary cancer metastasis through RANKL-RANK signalling. Nature. Vol. 470:pp548-553.

Thomas, D.A., \&J., M.(2005) TGF- $\beta$ directly targets cytotoxic T cell functions during tumor evasion of immune surveillance Cancer Cell. Vol. 8:pp369-380.

Todaro, M., Lombardo, Y., Francipane, M.G., Alea, M.P., Cammareri, P., Iovino, F., Di Stefano, A.B., Di Bernardo, C., Agrusa, A., Condorelli, G., Walczak, H., \&Stassi, G.(2008) Apoptosis resistance in epithelial tumors is mediated by tumor-cellderived interleukin-4. Cell Death Differ. Vol. 15:pp762-772.

Treilleux, I., Blay, J.Y., Bendriss-Vermare, N., Ray-Coquard, I., Bachelot, T., Guastalla, J.P., Bremond, A., Goddard, S., Pin, J.J., Barthelemy-Dubois, C., \&Lebecque, S.(2004) Dendritic cell infiltration and prognosis of early stage breast cancer. Clin Cancer Res. Vol. 10:pp7466-7474.

Ueno, T., Toi, M., Saji, H., Muta, M., Bando, H., Kuroi, K., Koike, M., Inadera, H., \&Matsushima, K.(2000) Significance of macrophage chemoattractant protein-1 in macrophage recruitment, angiogenesis, and survival in human breast cancer. Clin Cancer Res. Vol. 6:pp3282-3289.

Unutmaz, D., Xiang, W., Sunshine, M.J., Campbell, J., Butcher, E., \&Littman, D.R.(2000) The primate lentiviral receptor Bonzo/STRL33 is coordinately regulated with CCR5 and its expression pattern is conserved between human and mouse. J Immunol. Vol. 165:pp3284-3292.

Vabulas, R.M., Braedel, S., Hilf, N., Singh-Jasuja, H., Herter, S., Ahmad-Nejad, P., Kirschning, C.J., Da Costa, C., Rammensee, H.-G., Wagner, H., \&Schild, H.(2002) The endoplasmic reticulum-resident heat shock protein Gp96 activates dendritic 
cells via the Toll-like receptor 2/4 pathway. Journal of Biological Chemistry. Vol. 277:pp20847-20853

Valković, T., Lucin, K., Krstulja, M., Dobi-Babić, R., \&Jonjić, N.(1998) Expression of monocyte chemotactic protein-1 in human invasive ductal breast cancer. Pathol Res Pract. Vol. 194:pp335-340.

Van Poznak, C., Cross, S.S., Saggese, M., Hudis, C., Panageas, K.S., Norton, L., Coleman, R.E., \&Holen, I.(2006) Expression of osteoprotegerin (OPG), TNF related apoptosis inducing ligand (TRAIL), and receptor activator of nuclear factor kappaB ligand (RANKL) in human breast tumours. J Clin Pathol. Vol. 59:pp56-63.

Vazquez-Martin, A., Colomer, R., \&Menendez, J.A.(2007) Protein array technology to detect HER2 (erbB-2)-induced 'cytokine signature' in breast cancer. Eur J Cancer. Vol. 43:pp1117-1124.

Walser, T.C., Ma, X., Kundu, N., Dorsey, R., Goloubeva, O., \&Fulton, A.M.(2007) Immunemediated modulation of breast cancer growth and metastasis by the chemokine Mig (CXCL9) in a murine model. J Immunother. Vol. 30:pp490-498.

Walser, T.C., Rifat, S., Ma, X., Kundu, N., Ward, C., Goloubeva, O., Johnson, M.G., Medina, J.C., Collins, T.L., \&Fulton, A.(2006) Antagonism of CXCR3 inhibits lung metastasis in a murine model of metastatic breast cancer. Cancer Res. Vol. 66:pp7701-7707.

Wang, B., Badura, M., He, C., Cameron, T., Dustin, M., Formenti, S.C., Schneider, R.J., \&Demaria, S.(2006) CXCR6 and CXCL16 are expressed by breast cancer cells and may play a dual role in tumor progression Breast Cancer Res Treat. Vol. 100:ppS299.

Wang, J., Lu, Y., Wang, J., Koch, A.E., Zhang, J., \&Taichman, R.S.(2008) CXCR6 induces prostate cancer progression by the AKT/mammalian target of rapamycin signaling pathway. Cancer Res. Vol. 68:pp10367-10376.

Wrzesinski, S.H., Wan, Y.Y., \&Flavell, R.A.(2007) Transforming growth factor-beta and the immune response: implications for anticancer therapy. Clin Cancer Res. Vol. 13:pp5262-5270.

Yamauchi, R., Tanaka, M., Kume, N., Minami, M., Kawamoto, T., Togi, K., Shimaoka, T., Takahashi, S., Yamaguchi, J., Nishina, T., Kitaichi, M., Komeda, M., Manabe, T., Yonehara, S., \&Kita, T.(2004) Upregulation of SR-PSOX/CXCL16 and recruitment of CD8+ $\mathrm{T}$ cells in cardiac valves during inflammatory valvular heart disease. Arterioscler Thromb Vasc Biol. Vol. 24:pp282-287.

Yang, H., Zhou, H., Feng, P., Zhou, X., Wen, H., Xie, X., Shen, H., \&Zhu, X.(2010) Reduced expression of Toll-like receptor 4 inhibits human breast cancer cells proliferation and inflammatory cytokines secretion. Journal of Experimental $\mathcal{E}$ Clinical Cancer Research. Vol. 29:pp92.

Yu, L., \&Chen, S.(2008) Toll-like receptors expressed in tumor cells: targets for therapy. Cancer Immunol Immunother. Vol. 57:pp1271-1278.

Zeh, H.J.r., \&Lotze, M.T.(2005) Addicted to death: invasive cancer and the immune response to unscheduled cell death. J Immunother. Vol. 28:pp1-9.

Zhou, M., McFarland-Mancini, M.M., Funk, H.M., Husseinzadeh, N., Mounajjed, T., \&Drew, A.F.(2009) Toll-like receptor expression in normal ovary and ovarian tumors. Cancer Immunol Immunother. Vol. 58:pp1375-1385. 
Zitvogel, L., Apetoh, L., Ghiringhelli, F., André, F., Tesniere, A., \&Kroemer, G.(2008) The anticancer immune response: indispensable for therapeutic success? J Clin Invest. Vol. 118:pp1991-2001.

Zitvogel, L., Kepp, O., \&Kroemer, G.(2010) Decoding cell death signals in inflammation and immunity. Cell. Vol. 140:pp798-804.

Zitvogel, L., Kepp, O., \&Kroemer, G.(2011) Immune parameters affecting the efficacy of chemotherapeutic regimens. Nat Rev Clin Oncol. Vol. 8:pp151-160,I S S N 


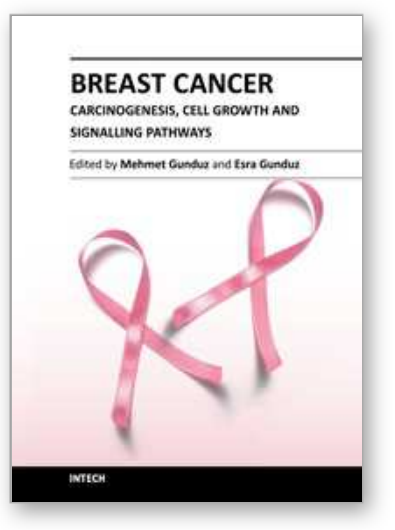

\author{
Breast Cancer - Carcinogenesis, Cell Growth and Signalling \\ Pathways \\ Edited by Prof. Mehmet Gunduz
}

ISBN 978-953-307-714-7

Hard cover, 732 pages

Publisher InTech

Published online 30, November, 2011

Published in print edition November, 2011

Cancer is the leading cause of death in most countries and its consequences result in huge economic, social and psychological burden. Breast cancer is the most frequently diagnosed cancer type and the leading cause of cancer death among females. In this book, we discussed various aspects of breast cancer carcinogenesis from clinics to its hormone-based as well as genetic-based etiologies for this deadly cancer. We hope that this book will contribute to the development of novel diagnostic as well as therapeutic approaches.

\title{
How to reference
}

In order to correctly reference this scholarly work, feel free to copy and paste the following:

Sandra Demaria, Karsten A. Pilones and Sylvia Adams (2011). Cross-Talk of Breast Cancer Cells with the Immune System, Breast Cancer - Carcinogenesis, Cell Growth and Signalling Pathways, Prof. Mehmet Gunduz (Ed.), ISBN: 978-953-307-714-7, InTech, Available from: http://www.intechopen.com/books/breastcancer-carcinogenesis-cell-growth-and-signalling-pathways/cross-talk-of-breast-cancer-cells-with-the-immunesystem

\section{INTECH}

open science | open minds

\section{InTech Europe}

University Campus STeP Ri

Slavka Krautzeka 83/A

51000 Rijeka, Croatia

Phone: +385 (51) 770447

Fax: +385 (51) 686166

www.intechopen.com

\section{InTech China}

Unit 405, Office Block, Hotel Equatorial Shanghai

No.65, Yan An Road (West), Shanghai, 200040, China

中国上海市延安西路65号上海国际贵都大饭店办公楼 405 单元

Phone: +86-21-62489820

Fax: +86-21-62489821 
(C) 2011 The Author(s). Licensee IntechOpen. This is an open access article distributed under the terms of the Creative Commons Attribution 3.0 License, which permits unrestricted use, distribution, and reproduction in any medium, provided the original work is properly cited. 